\title{
Magic in the Spanish Golden Age: Cervantes's Second Thoughts*
}

\author{
STEPHEN HARRISON
}

$\mathrm{M}$ Many authorities attest to a belief in magic and the continuing practice of witchcraft in the sixteenth century ${ }^{1}$ and, even among enlightened persons, to a lingering belief in astrology. Jean Seznec attributes this belief to the authority of the literature and philosophy of late antiquity, ${ }^{2}$ and Cassirer states that "The basic magical-astrological view of causality is strongly interwoven in the whole Renaissance philosophy of nature, from its inception in the fifteenth, throughout its life in the sixteenth, and even through the beginnings of the seventeenth century." 3 C.S. Lewis makes the point that, whilst the Medieval church objected to "astrological determinism," it did not disapprove of astrology as such. ${ }^{4}$

In Spain, the casting of spells with both good intent ("ensalmos") and bad (as "conjuros" usually were) is evidenced by the penalties exacted from specific practitioners referred to in the records of the Inquisition; yet some of the practices prohibited by the Holy Office are, Rodriguez Marín claims, still to be found in the twentieth century, and Lecky notes that a man was burnt for sorcery in Spain as late as 1780.5 Rodríguez Marín also adduces evidence to show that Philip II himself had recourse to alchemists in an attempt to swell the royal coffers. $^{6}$

Persiles $y$ Sigismunda, more than any other novel of Cervantes, has raised the question of the author's attitude to miracles and the supernatural. This Byzantine novel, published posthumously in 1617, and possibly written over a period of many years, ${ }^{7}$ contains episodes where magic plays an important role: the casting of spells, astrological projections, a witch turned into a wolf, a flight on a magic carpet. These incidents are, in many instances, surrounded by authorial rationalizations, protestations of orthodoxy, and declarations that magic is the work of the Devil, dependent strictly on the will of God.

The prevalence of superstitious beliefs in the sixteenth century may nevertheless explain some critics' assumption that Cervantes himself

* I thank Professor Stagg for some very helpful comments on this article. 
gave credence to the supernatural elements in his novel. For example, Cesare De Lollis says of Rutilio's description of his flight on a magic carpet, "Lo racconta in buona fede: gli credono i suoi ascoltatori: ci crede anche Cervantes", 8 and in a note on this tale, Luisa Banal says, "Circa le streghe e gli stregoni, il Cervantes sembra convidere le idee superstiziose del suo tempo...."9 Astrana Marín does not specifically commit himself to stating that Cervantes believed in the magic elements of the Persiles, but says, following his reference to descuidos in the novel, that "Otros lunares (hechizos y astrologia judiciaria) pertenecen a las ideas y supersticiones de la época." 10

It may well be, as Manuel Durán says, that Cervantes took advantage of the general public's acceptance of marvels as a result of news of the wonders of the New World, ${ }^{11}$ and that at one time this contributed to his confidence in the acceptability of irrational elements in a fictional work. But contradictions in the Persiles surrounding the possible efficacy of magic have understandably led to doubt about the author's attitude to this aspect of the novel. Cotarelo, for example, confesses, "No resulta tan diáfano el pensamiento de Cervantes en orden a la Magia negra o Magia propiamente dicha," but adds, "Dificúltale el pronunciarse con franqueza por la negativa la posible intervención diabólica en que, naturalmente, creía." 12 Yet, as Américo Castro says, it seems hardly credible that Cervantes could believe in magic carpets. ${ }^{13}$

None of the foregoing observations, however, helps us to understand why, since these fantastic episodes are merely literary elements, the novel contains so many references to the fact that incidents are not really miraculous. Moreover, the function of some of these references is itself somewhat perplexing. For example, Cenotia says magic potions are powerless to influence free-will (Bk. II. Ch. 8), yet her own are later seen to be effective on Antonio (Bk. II, Ch. 11). The enchantments of Julia are effective in Bk. IV, Ch. 8, and it is not until Ch. 10 that they are said to have depended on God's will; similarly, Antonio is addressed by a wolf in Bk. I, Ch. 5, and only in Ch. 8 is lycanthropy explained as a punishment from God. The magic shirt of Domicio in Persiles III:15, is, surprisingly, accompanied by no orthodox disclaimer.

It is difficult, therefore, to accept Juan Bautista Avalle-Arce's analysis of the function of the miraculous in the Persiles: "Dentro de este marco universal-absoluto de Persiles creo que hay que buscar el sentido de los abundantes milagros de la novela"; and "La profusión de supuestos milagros. . .es como la ascesis previa necesaria para la intelección de la Verdad Absoluta." 14 For oen of the major difficulties in interpreting the novel is the fact that even events that an orthodox Catholic might fairly accept as miracles are specifically said not to be so. Thus, Auristela and Constanza take refuge in a church as the village burns around them, 
and pray to God for deliverance from the present danger. They are saved because the church remains untouched by the flames, yet this is said to be "no por milagro, sino porque las puertas eran de hierro, y fue poco el fuego que se les aplicó." 15 The same disinclination to admit even the most orthodox miracle can be found also in Rutilio's sonnet in Persiles I:18:

Vense en la excelsa máquina encerrarse el león y el cordero, y en segura

paz, la paloma al fiero unida;

sin ser milagro, lo discorde amarse:

que en el común peligro y desventura

la natural inclinación se olvida. ${ }^{16}$

This example is the more remarkable, since the first tercet is so reminiscent of the Biblical phrase "And the wolf shall dwell with the lamb" (Isaiah, $X I, 6)$ that the secular note of the concluding lines cannot fail to surprise the reader. A recent study of the novel by Alban Forcione entitled Cervantes' Christian Romance ${ }^{17}$ barely addresses itself at all to this curious aspect of the novel.

Avalle-Arce draws attention to the fact that Cervantes frequently presents remarkable incidents "e inmediatamente después el autor se fatiga en enseñarnos los resortes perfectamente racionales que produjeron tal hecho." 18 E.C. Riley suggests that what Cervantes seeks to do in this novel is "to retain the charm of the supernatural but to divest it of authority," 19 and that, for Cervantes as for Tasso, one of the most important problems of literary creation was to reconcile admiratio, which arises from the extraordinary and the marvellous, with verisimilitude. ${ }^{20}$ Yet, if Cervantes's guiding aesthetic principle in the writing of the Persiles had been to balance the demands of verisimilitude and the need to entertain and surprise his readers, he would surely have avoided such obvious anomalies as the magic shirt, and spells that are seen sometimes as the effective work of a witch and sometimes as dependent on the intervention of an avenging God. At the very least, one would expect him to precede or conclude all such elements with a rational disclaimer. It is, moreover, unclear why Cervantes should seek to divest the supernatural of its authority in a work of the imagination. If his readers did not believe in witchcraft they hardly needed such a novel to support their scepticism, and, if they did believe in supernatural manifestations, the haphazard disclaimers of Persiles $y$ Sigismunda were not likely to shake their belief.

But it is certainly true that fantastic elements and rationalizations of the marvellous are both present in the novel. The former are essential to the plot, particularly of the first two Books, and to a lesser extent 
of Bks. III and IV; the latter are limited to incidental remarks on the part either of characters or the narrator. We shall attempt to show that a gulf exists between rational disclaimers and the effective course of events in the novel, and that this gulf and the curious placing of some of these disclaimers are evidence that Cervantes had second thoughts about irrational elements in the romance after it was substantially complete.

Recapitulations of events occur at several points in the narrative of the Persiles ${ }^{21}$ and the most unusual of these occurs in Persiles III:19. The pilgrims have just been invited to dine with Soldino, who is not yet dismissed entirely from the story, for in the third paragraph of Ch. 19 we read, "Acabóse la breve comida, salió Soldino con todos los que con él estaban al camino, para despedirse dellos...." (ed. cit., p. 398). Soldino also predicts that Bartolomé will repent of his theft of the baggage. In a sense, this is the continuation of the tale, for the meal is hardly described, and nothing occurs during it. The first two paragraphs of the chapter therefore require special attention:

Aderezóse la pobre más que limpia comida, aunque fue muy limpia cosa, no muy nueva para los cuatro peregrinos, que se acordaron entonces de la Isla Bárbara y de la de las Ermitas, donde quedó Rutilio, y adonde ellos comieron los ya sazonados, y ya no, frutos de los árboles; también se les vino a la memoria la profecía falsa de los isleños y las muchas de Mauricio, con las moriscas del jadraque, y últimamente, las del español Soldino.

Parecíales que andaban rodeados de adivinanzas y metidos hasta el alma en la judiciaria astrología, que a no ser acreditada con la esperiencia, con dificultad le dieran crédito. (ed. cit., pp. 397-398).

There seems no reason, in the present circumstances, why the characters should "remember" the islands of the first two Books (they are not said to be describing their adventures to Soldino), still less the details of the fruits. Moreover, whilst the prophecies of Mauricio may well be called to mind from past memory, those of Soldino, barely completed, can hardly be the subject of memory. It is unusual, to say the least, that this long, dramatic prediction of their fortunes immediately "se les vino a la memoria." Nor is it immediately clear why they should, at this particular point, become self-conscious about astrological projections, which they have not queried before. Indeed, they are said specifically to accept them, because experience has led them to do so. But what experience? The prophecies of the islanders were false, and the prophecies of the jadraque and Soldino yet remain to be fulfilled; there remains only the case of Mauricio, who had foretold one of the infinite number of disasters that befell them (Persiles I:19). These two paragraphs can be explained most logically as the result of Cervantes's own review 
of the novel and his own reminder to the reader of the previous shape of events. Moreover, the implication that Soldino's and the jadraque's claims will come true serves, we believe, a quite specific purpose.

We have pointed out that this material occurs in two paragraphs separate from the continuation of the tale, and that the characters' supposed uneasiness about astrological prophecy comes as a surprise to the reader. It would seem that Cervantes not only reviewed the story, but himself became uneasy about some irrational elements, the number of which would strike him afresh on a re-reading. He therefore voiced his doubts through his characters, and attempted to justify his novelistic practice with a suggestion that these predictions are reliable.

But it was also mentioned that the Soldino episode is not at this point complete, and that he makes a further prediction. This would, then, be an unusual point at which to stop to review the earlier part of the novel, and it would be illogical to conceive doubts about an aspect of the story and reintroduce it immediately afterwards. Logically, we can only believe that the two paragraphs in question were interpolated some time after the composition of the remainder of $\mathrm{Ch} .12$. The most convenient place to insert this matter would be at the beginning of a chapter, thus avoiding modification of other material but thereby leaving the anomalies we have discovered.

Whilst it is obviously not possible to adduce evidence to show that each individual attempt to explain away irrational elements is an interpolation, some orthodox disclaimers are in contradiction to narrated events or lead to inconsistent characterization, and are for that reason suspect. On occasion, it is their position in the novel that leads us to doubt that they could originally have occupied their present place.

The most obviously misplaced of these disclaimers occurs during Rutilio's tale in Persiles I:8. It will be recalled that, in this story, the dancing-master describes a magical flight which takes him to Norway, where his helper the witch turns into a wolf as she embraces him. As he stabs her, she resumes her original form and falls dead at his feet. Following this incident, he encounters some natives, one of whom speaks Italian, and to whom he tells his misfortune. The narrative continues,

Mostró condolerse el que me hablaba, y díjome:

- Puedes, buen hombre, dar infinitas gracias al cielo por haberte librado del poder destas maléficas hechiceras, de las cuales hay mucha abundancia en estas septentrionales partes. Cuéntase dellas que se convierten en lobos, así machos como hembras, porque de entrambos géneros hay maléficos y encantadores. Como esto pueda ser yo lo ignoro, y como cristiano que soy católico no lo creo. Pero la esperiencia me muestra lo contrario. Lo que puedo alcanzar es, que todas estas 
transformaciones son ilusiones del demonio, y permisión de Dios y castigo de los abominables pecados deste maldito género de gente.

- Preguntéle que [sic] hora podría ser, porque me parecía que la noche se alargaba, y el día nunca venía. ${ }^{22}$

As far as we can ascertain, no critic has commented on the extraordinary juxtaposition of ideas at the end of this passage. It surely requires an explanation. One speaker is giving a spirited explanation to the other of the workings of divine wrath, whereupon his new acquaintance calmly interrupts to ask him the time of day! If Rutilio had been presented as a rude and insensitive character, his question would be understandable. But he is not shown as such; his worst sin was to fall in love with one of his pupils, an error for which he seeks to make amends later in the novel by becoming a hermit. ${ }^{23}$ His question about the time is not in itself unreasonable, for it relates to his earlier observation of the uneven length of days in the Northern lands. It would be understandable if it followed the brief recapitulation of events that he has just given to the Norwegian, and it would not seem too abrupt if it followed the latter's reference to "maléficos y encantadores."

The last half of the Norwegian's speech contains an element we have already encountered in a suspect passage. This is the reference, in Persiles III:19, to astrology "que a no ser acreditada con la esperiencia, con dificultad le dieran crédito." ${ }^{24}$ The claim that supernatural manifestations are a diabolical illusion permitted by God is a sentiment we shall encounter in other passages we feel to be interpolated.

It would seem, then, that the Norwegian's speech, probably from "Come esto pueda ser..." to the end, must have been a later addition whose aim was to introduce a note of orthodoxy. The fact that the remarks are not integrated into the dialogue by some comment or sign of agreement on Rutilio's part suggests that the insertion was made in some haste. This would account for the Norwegian's confused position, which arises from the fact that Cervantes cannot make him question the truth of an incident without calling Rutilio a liar. The speaker adopts a self-contradictory attitude when he says that, as a Catholic, he does not believe something that his experience tells him to be so and that God himself permits. This allows Cervantes to retain the incident of the witch's transformation but still hope to avoid a charge of unorthodoxy or naivety.

A similar anomaly occurs in the case of the powers ascribed to Cenotia in Bk. II and to Julia in Bk. IV.

In Persiles II:8, Cenotia says she has inherited both her name and "esta ciencia, que no nos enseña a ser hechiceras, como algunos nos llaman, sino a ser encantadoras y magas, nombres que nos vienen más al propio. Las que son hechiceras. . .usan de caracteres que no entienden, 
y si algo alcanzan, tal vez, de lo que pretenden, es, no en virtud de sus simplicidades, sino porque Dios permite para mayor condenación suya, que el demonio les engañe. Pero nosotros, las que tenemos nombre de magas y encantadoras, somos gente de mayor cuantía...."25 It emerges from this speech that Cenotia is not a witch, and that only God permits witchcraft. However, in Persiles II:11, she is treated as a witch whose spells are entirely successful: "Sacó del quicio de una puerta los hechizos que habia preparado," and "Apenas hubo sacado la Cenotia sus endemoniados preparamentos de la puerta, cuando salió la salud perdida de Antonio a plaza." 26 There is no suggestion in this case that Cenotia was working merely as the unconscious agent of God, but it is to be admitted that Antonio's father tells him, "La Cenotia te tenía hechizado, y con hechizos de tiempo señalado, poco a poco, en menos de diez días perdieras la vida, si Dios y mi buena diligencia no lo hubiera estorbado." But here the reference "Dios y mi buena diligencia" reads merely as a polite formula, and cannot accurately be related to Cenotia's speech in Ch. 8. It is also to be noted that Antonio the Elder accuses Cenotia with the words "Mira si tienes su vida envuelta en algún envoltorio de agujas sin ojos o de alfileres sin cabezas; mira, ioh pérfida!, si la tienes escondida en algún quicio de puerta...."27 Cenotia does not deny that her spell is of this kind and the reader assumes that this is the charm she later removes. But in her earlier speech Cervantes has her say that she is not the type of woman who employs tricks "como son habas mordidas, agujas sin puntas, alfileres sin cabeza, y cabellos cortados en crecientes o menguantes de luna." 28

Clearly, the part of Cenotia's speech quoted from Ch. 8 is inconsistent with events in Ch. 11. Her magic powers are consistent with the other supernatural elements in the Persiles and must be part of the original tale, but some of her earlier speech could have been interpolated without difficulty, for it is isolated from the narration of events. Apart from the introduction of an orthodox note in the reference to God's will, it also adds a note of caution on the subject of miracles ("parece que hacemos milagros"29) and concludes with a preoccupation we shall refer to later in our attempt to date this kind of interpolation: "Puesto que en mudar las voluntades, sacarlas de su quicio, como esto es ir contra el libre albedrío, no hay ciencia que lo pueda, ni virtud de yerbas que lo alcancen." 30 It should be noted that the reference "no hay ciencia" is inconsistent with "lo mucho que con su ciencia se prometía".31

The inconsistency surrounding the role of Cenotia is similar to that surrounding the powers of Julia, the wife of Zabulón, who is approached by Hipólita to cast a spell on Auristela. Hipólita has failed to seduce Periandro, so, in $\mathrm{Bk}$. IV, $\mathrm{Ch}$. 8, resorts to witchcraft in an attempt to render Auristela physically repulsive to him. If this stratagem fails, the 
courtesan is resolved to employ a spell that will kill the heroine. "Esto dijo Zabulón ser cosa fácil al poder y sabiduría de su mujer." ${ }^{32}$ Their plot is immediately successful: "Y otro día por la mañana comenzaron a obrar en Auristela los hechizos, los venenos, los encantos y la malicia de la judía, mujer de Zabulón." ${ }^{33}$ At the opening of Ch. 10, we observe Hipólita exulting in her triumph, and the others amazed and confused:

Contentísima estaba Hipólita de ver que las artes de la cruel Julia tan en daño de la salud de Auristela se mostraban, proque en ocho días la pusieron tan otra de la que ser solía, que ya no la conocían sino por el órgano de la voz; cosa que tenía suspensos a los médicos y admirados a cuantos la conocían. ${ }^{34}$

It therefore surprises the reader that Hipólita asks Julia to temper the power of the charm and that

Hízolo así la judía, como si estuviera en su mano la salud o la enfermedad ajena, o como si no dependieran todos los males que ilaman de pena, de la voluntad de Dios, como no dependen de culpa; pero Dios, obligándole, si así se puede decir, por nuestros mismos pecados, para castigo dellos, permite que pueda quitar la salud ajena esta que llaman hechicería, con que lo hacen las hechiceras; sin duda ha él permitido, usando mezclas y venenos, que con tiempo limitado quitan la vida a la persona que quieren, sin que tenga remedio de escusar este peligro, porque le ignora, y no sabe de donde procede la causa de tan mortal efeto; así que, para guarecer destos males, la gran misericordia de Dios ha de ser la maestra, la que ha de aplicar la medicina. ${ }^{35}$

As in the case of Cenotia's speech, the passage shows a belated desire to impose a rational explanation on a magical incident, attributing to God's will any power that a witch may appear to have. But the orthodox note is obtrusive and in contradiction to the narrative, so it would therefore seem to be an afterthought.

The passage we have just quoted can be compared with the episode in the "Coloquio de los perros" where the witch Cañizares says that, although she may have wrought evil, "todo esto lo permite Dios por nuestros pecados." She concedes that some of the gatherings she describes may have taken place only in her imagination, just as the unguents she uses are "tan frías que nos privan de todos los sentidos en untándonos con ellas, y quedamos tendidas y desnudas en el suelo, y entonces dicen que en la fantasía pasamos todo aquello que nos parece pasar verdaderamente...." ${ }^{36}$ In the case of the "Coloquio de los perros," these explanations are so woven into the text that there is no disparity between narrated incidents and rational disclaimers. By contrast, the Persiles passage ("Hízolo asi la judía. ..") confuses the reader. AvalleArce suggests it lacks polish but does not explain why he feels this. ${ }^{37}$ 
The signs of carelessness that we have found in the passages rationalizing lycanthropy and the powers of Julia may be taken as a sign that Cervantes did not approach this aspect of his revision with the necessary attention to detail. It is difficult to account otherwise for the present version of the incident of the enchanted shirt (Persiles III:15). This is part of the story of Claricia, who tells how the jealous Lorena sent shirts of outstanding handiwork to the man who had once loved her. But the garments were charmed and "Apenas se puso una cuando perdió los sentidos, y estuvo dos días como muerto, puesto que leugo se la quitaron, imaginando que una esclava de Lorena, que estaba en opinión de maga, la habria hechizado." 38 When the shirt is removed he partly recovers, though is left insane by the incident.

The narrator does not attempt to rationalize this occurrence, which passes without comment or signs of disbelief on the part of listeners. An explanation for this can be offered. The Claricia incident begins in Ch. 14 with her remarkable leap from the high tower, to which Cervantes does add a rational explanation, and the fall of Periandro, which causes general consternation; the tale is interrupted by an attack by armed men, who are repelled by Antonio. Ch. 15 opens with a description of the despair of Auristela and Constanza, then continues Claricia's tale, including the gift of the shirts. Since the enchantment of Domicio occupies such a small part of these incidents it is understandable that Cervantes may have overlooked it, if we imagine him composing these rationalizations some time after the composition of the body of the novel.

Although these frankly supernatural incidents are the most remarkable of the irrational elements in the novel, there are several of less importance that Cervantes seeks to make more palatable to his readers. They concern characters' predictions of events and some simply surprising incidents that the author is at pains to explain are not outside the natural order of things.

In Persiles II: 2 the boat in which Auristela and some of her companions are travelling is washed up on the shores of Policarpo's isle. Sounds can be heard from within the boat which prompt an old gentleman standing near the spot to observe to the King that he recalls an incident in which a Spanish galleon with no signs of life aboard was wrecked near Genoa and that, on hearing a noise and peering inside, some bystanders discovered sailors within who disembarked safely. He adds that he himself saw this, and that some of those who were saved may still be alive.

This singularly unremarkable observation is followed by a note of warning: "y si aquí sucediese lo mismo, no se ha de tener a milagro, sino a misterio; que los milagros suceden fuera del orden de la naturaleza, 
y los misterios son aquellos que parecen milagros y no lo son, sino casos que acontecen raras veces." ${ }^{39}$ Avalle-Arce notes that this reflects a quite orthodox position, ${ }^{40}$ but it requires further comment because it is prompted by an incident that would hardly be taken as literally miraculous by those present. It is additionally interesting because Policarpo responds, "Pues, ¿a qué aguardamos?... Siérrese luego el buco, y veamos este misterio, que si este vientre vomita vivos, yo lo tendré por milagro. ${ }^{41}$

It might appear that Cervantes is simply establishing the King's character by giving him a remark that marks his independence from the previous attitude. Nevertheless, since the old man's statement is one of orthodox belief, Policarpo's statement does seem strange. Either it or the foregoing remark appears out of place.

The problem surrounding this exchange can be clarified if we take into consideration other incidents in the novel where an explanatory note is added to a readily understandable situation.

In Persiles III:16, whilst the pilgrims are in France, they encounter a young girl who addresses Constanza in Spanish, telling her she is from Talavera de la Reina. This Castilian town appears earlier in Bk. III, in the long episode during which Ortel Banedre tells the travellers how he there married a girl named Luisa, who tricked him and was finally imprisoned for theft and adultery. It occurs to Constanza that their new acquaintance may be Banedre's wife, and she announces this in the presence of Periandro and Auristela, repeating some details from Banedre's tale. Luisa, who does not know that the pilgrims have met her husband and heard the story of her misdeeds, is naturally amazed at this recital of incidents from her past life: "- ¡Ay, cielos santos! ... ¿Y quién es esta señora que me ha leído mis pensamientos? ¿Quién es esta adivina que ansí sabe la desvergonzada historia de mi vida? ${ }^{42}$

The incident would require no further comment, were it not that Constanza's announcement is preceded by an explanation of what she calls the science of divination, and a statement that implies she is known by the others to be versed in this science: "- Señores, vosotros estáis dudosos de que si la ciencia que yo tengo de adevinar es falsa o verdadera, la cual ciencia no se acredita con decir las cosas que están por venir, porque sólo Dios las sabe, y si algún humano las acierta, es acaso, o por algunas premisas a quien la esperiencia de otras semejantes tiene acreditadas." 43 This speech goes out of its way to ascribe to the power of God an incident that the speaker fears may be regarded as outside the natural order, though it is merely the prelude to a lucky guess, and the rationalization is as surprising as in the incident of the survivors of the shipwreck in Persiles II:2. It seems, moreover, to fall on deaf ears, for Luisa's reaction is not a concession to Constanza's preamble, but a 
declaration that she must indeed be an "adivina," a soothsayer: “¿Quién es esta adivina que ansí sabe la desvergonzada historia de mi vida?" This might seem to be the point at which Constanza should explain her art, but for her to do so would have required interrupting Luisa's speech. The position of the rationalizing passage is understandable if we imagine it to be an interpolation performed in such a way as to require the least re-writing. This will also account for Constanza's opening statement, which abruptly introduces the news that her companions know she is a soothsayer and have previously questioned her skill: the statement merely acts as an excuse for the discussion of divination, and the manner in which this new facet to her character is introduced suggests haste in writing.

This is not the only occasion on which Cervantes shows concern about the unorthodoxy of divination. The encounter with Soldino is marked by several rational disclaimers, which again do not impinge on the substance of the incident or on Soldino's character as a practitioner of astrology.

The pilgrims encounter Soldino in a hostelry where he predicts that the merry-making will lead to a fire that will consume almost the entire house. Croriano is prompted to say to Ruperta, " - Este sin duda, debe ser mágico o adivino, pues predice lo por venir. .. ", a remark overheard by Soldino, who states: " - No soy yo mago ni adivino sino judiciario, cuya ciencia, si bien se sabe, casi enseña a adivinar." 44 This exchange is, of course, inconsistent both with Constanza's definition of "adivina," which is specifically stated to be limited to knowing the past, and with Soldino's later actions: whether he accepts the title magus, soothsayer or astrologer does not alter the fact that he most certainly can tell the future, for he predicts an event not only here, but also in Bk. III, Ch. 18, where he foretells the destiny of the pilgrims, and in Ch. 19, where he assures them that the unreliable Bartolomé will return. So his statement "no soy yo mago..." seems to be an afterthought on the part of the author, just as we suggested that the passage in the following chapter questioning soothsaying was an interpolation.

The evidence we have adduced to show that some passages reflecting a preoccupation with orthodoxy are probably interpolations entitles us to view other elements of this nature as suspect. Thus, the exchange between King Policarpo and an old gentleman, discussed earlier in this paper, can be explained by the proposition that the gentleman's speech from "y si aquí sucediese lo mismo" is an interpolation, prompted, as Cervantes reviewed his work, by Policarpo's reference to a miracle. It would seem likely that most references to the fact that surprising events are not to be thought miraculous are the result of the same process of revision: the "mujer voladora" of Persiles III:14, "cosa posible sin ser 
milagro," the church which is saved from fire in Persiles III:11, "no por milagro," and peace among the creatures of the earth in Persiles I:18, "sin ser milagro." 45

We have already made the point that theoretical statements on the nature of supernatural phenomena are not always consistent with events narrated in the novel. It would also be wrong to leave the impression that we find all such statements are themselves consistent, for there is some disparity here that tends to support the contention that the process of revision was performed in haste and never completed. First, a minor inconsistency can be noted that may reveal the author's own uncertainty. Soldino declares in Persiles III:18 that the science of astrology "casi enseña a adivinar," a captious remark that leaves the reader in doubt about the speaker's belief, ${ }^{46}$ and which is, strictly speaking, not the same as Constanza's self-acclaimed "ciencia... de adevinar." 47 Constanza does, it is true, take care to add that she has insight only into past events, and in this sense makes no greater a claim than Soldino. Yet there still remains an inconsistency between Constanza's definition of "adivinar" as referring to the past, and the implication of Soldino's statement, where "adivinar" is clearly used in connection with knowledge of the future. The important disparity in the novel lies between the supposed power of these two characters and that of Mauricio. Constanza, as we have seen, declares that the science of astrology "no se acredita con decir las cosas que están por venir, porque Dios sólo las sabe, y si algún humano las acierta, es acaso, o por algunas premisas a quien la esperiencia de otras semejantes tiene acreditadas." 48 Mauricio, in Persiles I:13, although be gives the same weight to the value of experience, also makes a significantly different claim about knowledge of the future:

ninguna ciencia, en cuanto a ciencia, engaña: el engaño está en quien no la sabe, principalmente la del [sic] astrología,...: y así el astrólogo judiciario si acierta alguna vez en sus juicios, es por arrimarse a lo más probable y a lo mas esperimentado, y el mejor astrólogo del mundo, puesto que muchas veces se engaña, es el demonio, porque no solamente juzga de lo por venir por la ciencia que sabe, sino también por las premisas y conjeturas; y como ha tanto tiempo que tiene esperiencia de los casos pasados y tanta noticia de los presentes, con facilidad se arroja a juzgar de los por venir, lo que no tenemos los aprendices desta ciencia, pues hemos de juzgar siempre a tiento y con poca seguridad. Con todo eso, alcancé que tu perdición había de durar dos años. ${ }^{49}$

Mauricio, then, claims he has predicted the future, but modestly admits that his powers as an astrologer are limited because he is a mere tyro. (His skill is further confirmed when he successfully predicts in Persiles I: 18 that their boat will sink, and the cautious nature of his present 
claim is, we feel, to be taken as a character trait and not as a sign of authorial rationalization.) Mauricio also says that the devil, too, although he frequently errs, is one of the best predictors of the future - a sentiment in direct contradiction to the position taken by Constanza.

It might seem that these differences merely reveal that characters in the novel not unexpectedly hold independent views. Yet considering that rationalizing statements seem to be interpolations, and that some are expressed by the narrator and not exclusively by characters, Mauricio's speech and the powers ascribed to him can fairly be taken to be signs of an incomplete revision of the text.

The question of supernatural intervention in human affairs is raised in other works of Cervantes, and this fact will provide a context for discussion of the period when this aspect of revision in the Persiles may have been performed. As a general rule, it will be found that the unorthodoxy of supernatural phenomena in literature did not seem to preoccupy the author until later in life, if we are to judge by their use in the two Parts of Don Quixote and the Novelas ejemplares.

Mauricio and Soldino are not the only astrologers created by Cervantes. In Don Quixote, Pt. I, Ch. 12, it is revealed that Grisóstomo is also able to read the stars. The Cabrero tells us,

decían que [Grisóstomo] sabía la ciencia de las estrellas, y de lo que pasan, allá en el cielo, el sol y la luna, porque puntualmente nos decía el cris del sol y de la luna...

- Asimesmo adevinaba cuando había de ser el año abundante o estil... .

- Esta ciencia se llama astrología, dijo don Quijote. ${ }^{50}$

Apart from putting a name to this gift, the knight's only preoccupation is with correcting the Cabrero's speech, and nowhere does he or the narrator call into question the plausibility of the claim made for Grisóstomo. We should recall that in Persiles I:13 Mauricio's claim that . 1e can predict the future is not questioned either, but that Constanza : tates in an interpolated passage that her art does not extend to predictions, and that Soldino in a similarly suspect passage states only that he can "almost tell the future." It is interesting, however, that Cervantes does not deny Soldino the claim to be an astrologer, albeit with somewhat ill-defined powers.

There seems to be evidence in Don Quixote, Pt. II, Ch. 25, that the existence of a science of astrology is not entirely rejected. Here, Don Quixote takes Sancho aside and suggests to him that Maese Pedro's soothsaying monkey is inspired by a pact with the devil, and goes on to explain why the monkey and its master cannot be regarded as astrologers. The passage in question is relevant to our study for several 
reasons. It begins with a statement of the limitations of the devil's powers that is consistent with Constanza's speech in Persiles III:16 ("las cosas que están por venir... sólo Dios las sabe").Don Quixote says,

Y háceme creer esto el ver que el mono no responde sino a las cosas pasadas o presentes, y la sabiduría del diablo no se puede estender a más; que las por venir no sabe si no es por conjeturas, y no todas veces: que a sólo Dios está reservado conocer los tiempos y los momentos, y para El no hay pasado ni porvenir; que todo es presente. ${ }^{51}$

This is, of course quite a different position from Mauricio's, who states that the devil, although he makes many mistakes, "no solamente juzga de lo por venir por la ciencia que sabe, sino también por las premisas y conjeturas." 52

Don Quixote's speech continues with a criticism of people who presume to tell the future by superstitious practices that obscure the truth of science:

cierto está que este mono no es astrólogo, ni su amo ni él alzan ni saben alzar, estas figuras que llaman judiciarias, que tanto ahora se usan en España, que no hay mujercilla, ni paje, ni zapatero de viejo que no presuma de alzar una figura, como si fuera una sota de naipes del suelo, echando a perder con sus mentiras e ignorancias la verdad maravillosa de la ciencia. ${ }^{53}$

He continues with a description of a case of a woman who once consulted an astrologer who turned out to be a charlatan. It is important to underline the fact that the criticism made here seems to be of a misuse of an astrological practice, and not of astrology itself, which it would appear he regarded still as a science. ${ }^{54}$ The passage mocks the attempt to predict events by establishing the position of the stars and their relationship to the signs of the zodiac, ${ }^{55}$ though Mauricio, of course, employs this method with success in Persiles I:18, and there is no suggestion that he is foolish or superstitious: "Puso los ojos en el cielo Mauricio, y de nuevo tornó a mirar en su imaginación las señales de la figura que había levantado, y de nuevo confirmó el peligro que les amenazaba. ..."56

In the Persiles, astrology is briefly called into question once, in the passage we have quoted from Bk. III, Ch. 19, and this underlines an ambiguity in the novel that would seem to be the result of too hasty a revision. The evidence of Don Quixote would suggest that Cervantes's more critical attitude to possible abuses of astrology was a late one,${ }^{57}$ so this aspect of revision in the Persiles may have been the last work he did on the novel, and may have been work he did not have time to complete. We have suggested that there is an interpolation in Persiles II:8, at the point where Cenotia concedes that no magic potion can influence man's 
free will. This sentiment should be seen as a concern of Cervantes that is first revealed in its clearest form in Don Quixote, Pt. I, Ch. 22, where the knight remarks that "no hay hechizos en el mundo que puedan mover y forzar la voluntad...; que es libre nuestro albedrío, y no hay yerba ni encanto que le fuerce." 58 A similar passage occurs in "El licenciado Vidriera," after Tomás Rodaja takes a drug intended to force him to love a woman who has recently arrived in Salamanca. The drug is administered by a morisca, "creyendo que le daba cosa que le forzase la voluntad a quererla: como si hubiese en el mundo hierbas, encantos ni palabras suficientes a forzar el libre albedrío. . .."59 The earliest date proposed for this novel is $1604,{ }^{60}$ but it is interesting that Armand Singer believes the early history of Rodaja to be "clearly divorced from the body proper of the text." 61 This suggestion causes us to wonder if the passage we have quoted could have been composed considerably later than the rest of the tale, for it is only in late works that we encounter unequivocal statements of the theme of free-will.

For example, we read in Don Quixote, Pt. II, Ch. 66: "cada uno es artífice de su ventura," 62 and in Viaje del Parnaso, Ch. 4, "Tú mismo te has forjado tu ventura." 63 The Persiles, however, is inconsistent in the view it presents of fortune, fate and free-will, for whilst in Persiles II:5, we see Arnaldo "lamentándose amargamente de la fortuna que él mismo se fabrica," como no es posible que ninguno fabrique su fortuna, puesto que dicen que cada uno es el artífice della." 65 This tends to confirm our belief that the clear statement on the nature of free-will in the Persiles II: 8 passage is an interpolation.

The rationalization of events that occur "no por milagro" calls to mind a passage in Don Quixote, Pt. II, Ch. 60, where Don Quixote tells Roque Guinart, "el cielo, o Dios, por mejor decir, que es nuestro médico, le aplicará medicinas que le sanen, las cuales suelen sanar poco a poco, y no de repente y por milagro." 66 Again, the cautiously orthodox statement, occurring as it does late in Part II of the novel, suggests that the concern with rationality in the Persiles may indeed have been a late preoccupation of Cervantes.

Inconsistencies we have noted in the statement of the theme of freewill and in the rationalization of fantastic events themselves, and the disparity that still remains in the novel between theoretical statements on magic and the role it effectively plays in the story, should all be taken as signs that this aspect of revision was Cervantes's last work on the novel, and that he was probably unable to complete it. 


\section{2 / Renaissance and Reformation}

\section{Footnotes}

1 Menéndez y Pelayo, Historia de los heterodoxos españoles, Chapter 4, "Magos y hechiceros," bears witness to the widespread practice of magic in the sixteenth century and its condemnation by Vitoria, Pedro Ciruelo and others. See also J. Caro Baroja, "La Magia en Castilla durante los Siglos 16 y 17," in Algunos mitos españoles (Madrid: Editora Nacional), 2nd ed., 1944 ; and his Los brujos y su mundo (Madrid), 2nd ed., 1966.

2 The Survival of the Pagan Gods, trans. B.F. Sessions (New York: Pantheon Books 1953), p. 58. See also p. 60; even with the more enlightened attitude, "fear of the stars does not disappear" (Seznec's italics). Cicero provided classical authority: "Gentem quidem nullam video neque tam humanam atque doctam neque tam immanem atque barbaram, quae non significari futura et a quibusdam intellegi praedicique posse censeat",De divinatione (London: Heinemann, and Cambridge, Mass: Harvard University Press [Loeb Classical Library] 1959), p. 222.

3 The Individual and the Cosmos in Renaissance Philosophy, trans. Mario Domandi (New York: Barnes and Noble, 1963), p. 101.

4 The Discarded Image (Cambridge: Cambridge University Press, 1967), p. 103.

5 Francisco Rodríguez Marín, Ensalmos y conjuros en España y en América (Madrid: Revista de Archivos, Bibliotecas y Museos, 1927), esp. p. 27, where he cites the example of a prayer to Santa Bárbara for protection against storms. W.E.H. Lecky, History of the Rise and Influence of the Spirit of Rationalism in Europe (London: Longmans, Green and Co.), 2nd ed., 1904, vol. I, p. 5.

6 Felipe II y la alquimia (Madrid: Revista de Archivos, Bibliotecas y Museos, 1927), passim.

7 See Rafael Osuna, "Las fechas del Persiles," Thesaurus, 25 (1970), 383-433.

8 Cervantes reazionario (Florence: Sansoni, 1947), p. 197.

9 Miguel de Cervantes: Le peripezie di Persile e Sigismonda, n. 216, n. 7. Riley states that Cervantes follows Tasso in adhering to popular belief rather than "the exact truth about things which learned men rightly called impossible" (Cervantes's Theory of the novel, Oxford: Clarendon Press, 1962, p. 191).

10 Vida ejemplar y heroica de Miguel de Cervantes Saavedra, vol. 7, p. 444, n. 1.

11 “Cervantes y el realismo fluido," Insula, año 18, no. 200-201 (July-August, 1963), p. 3.

12 Cervantes lector (Madrid: Publicaciones del Instituto de España, 1943), p. 38, and cf. p. 35 : "Dífícil es precisar la verdadera actitud de Cervantes frente a la Astrología judiciaria, "cuya ciencia, si bien se sabe, casi enseña a adivinar,'... . Tal vez no quiso oponerse a la general corriente; tal vez creyó, como tantos, en sus augurios." Commenting on the same quotation from the novel (Persiles III:18), Novo states that Cervantes fluctuates here between good sense, Christian spirit, and the beliefs of his age (Bosquejo para una edición crítica de "Persiles y Sigismunda," p. 123).

13 El pensamiento de Cervantes (Madrid: Hernando, 1925), p. 95.

14 Deslindes cervantinos (Madrid: Edhigar 1961), pp. 74-75, Avalle-Arce's italics.

15 Los trabajos de Persiles y Sigismunda, ed. J.B. Avalle-Arce (Madrid: Clásicos Castalia, 1969), p. 358. We quote throughout from this edition.

16 Ed. cit., p. 132. Later, in Persiles III:14 the incident in which a woman's billowing skirts act as a parachute is described as a "Cosa posible, sin ser milagro" (p. 373). The event is said to be "más para ser admirado que creído" (p. 380).

17 Alban K. Forcione, Cervantes' Christian Romance. A Study of "Persiles y Sigismunda," (Princeton: University Press, 1972). He speaks merely of "a peculiar simultaneous introduction and negation of myth" (p. 62), and a "tension" arising therefrom (p. 69, n. 2); see also p. 97.

18 Deslindes cervantinos, p. 74. E.C. Riley says, "The Persiles is remarkable for its rationalizing," Cervantes's Theory of the Novel, p. 188.

19 Cervantes's Theory of the Novel, p. 198.

20 "Aspectos del concepto de admiratio," in Studia. Homenaje ofrecido a Dámaso Alonso (Madrid, 1963), vol. 3, pp. 173-183. 
21 Persiles I:15 (p. 123); I:23 (p. 158); II:2 (pp. 167-168); III:12 (p. 359); III:19 (p. 398); and at the end of the novel.

22 Ed. cit., p. 92.

23 Persiles $1 \mathrm{I}: 21$, p. 273. Riley exaggerates Rutilio's misdeeds in order to declare that Cervantes wished to show that "the character of the narrator was not such as to inspire confidence," and he speaks of "the doubt that surrounds the integrity of Rutilio" (Cervantes's Theory of the Novel, p. 193). In fact Rutilio's listeners are pleased with his tale (ed. cit., p. 95), and all the characters applaud his Christian desire to do penance (p. 273). He is presumptuous in addressing a letter to Policarpo, but he immediately realizes this as he tears up his note "arrepentido de su loco pensamiento" (p. 194). Mauricio points out that lycanthropy does not exist, but he does not question the flight on the enchanted mantle or the existence of enchanters (p. 135).

24 Ed. cit., p. 398.

25 Ed. cit., p. 201.

26 Ed. cit., p. 218. This anomalv is pointed out by Osuna, "Vacilaciones y olvidos de Cervantes en el Persiles," $A C, 11$ (1972), 69-85, esp. p. 83. Avalle-Arce is quite wrong to speak of "la actitud totalmente negativa de Cervantes respecto a las hechicerías y filtros amorosos" (ed. cit., p. 202, n. 199), in regard to the author's literary practice.

27 Ed. cit., pp. 217-218.

28 Ed. cit., p. 201.

29 Ibid., our italics.

30 Ed. cit., p. 202.

31 Ed. cit., p. 203. Later, in Bk. II, Ch. 17, she is said to curse her "engañadora ciencia" (p. 250).

3.2 Ed. cit., p. 450.

33 Ed. cit., p. 453.

34 Ed. cit., p. 456.

35 Ed. cit., pp. $457-458$.

36 We are indebted to Professor Stagg for drawing our attention to this point of comparison.

37 "Este párrafo está muy necesitado de esa última lima que no pudo darle Cervantes" (ed. cit., p. 458, n. 538).

38 Ed. cit., pp. 377-378.

39 Ed. cit., pp. 163-164.

40 Ed. cit., p. 163, n. 155.

41 Ed. cit., p.164.

42 Ed. cit., p. 382.

43 Ibid.

44 Ed. cit., p. 393.

45 It might be objected that, occurring in a sonnet, this phrase could not have been inserted with the ease or the haste we have found to characterize other interpolations of this kind. But it occurs at the beginning of a line, and could without difficulty have been substituted for some such original as 'como milagro' without affecting the rhythm of the verse.

46 Ed. cit., p. 393.

47 Ed. cit., p. 382.

48 Ibid.

49 Ed. cit., p. 116.

50 Ed. M. de Riquer (Barcelona: Jurentud), 1971, vol. I, p. 111. All quotations from Don Quixote are from this edition.

51 Ed. cit., vol. II, p. 726.

52 Ed. cit., Persiles, p. 116.

53 Ed. cit., Don Quixote, vol. II, p. 726. 


\section{4 / Renaissance and Reformation}

54 This is the interpretation of Castro (El pensamiento de Cervantes, 1 st ed., p. 100), who cites Ciruelo's Reprobación de las supersticiones (1556) as a typical sixteenth-century attempt to distinguish between a fantastic astrology and an astrology as a true science (Castro, p. 104).

55 "Levantar figura"; Covarrubias's definition, quoted by Avalle-Arce (ed. cit., p. 131, n. 102).

56 Ed. cit., p. 131.

57 Exactly how late Don Quixote, Pt. II, Ch. 25, was written is a question examined by Daniel Eisenberg, who argues, from the reference to Sancho's "lost" donkey and from archaisms in early chapters of Don Quixote, Pt. II, that Cervantes wrote up to Ch. 28 of Pt. II immediately following completion of Pt. I. ("El rucio de Sancho y la fecha de composición de la segunda parte de Don Quijote," NRFH, 25 (1976), 94-102). There is, however, a weakness in this thesis, for Eisenberg accepts Professor Stagg's arguments with regard to Cervantes's revision of Don Quixote, Pt. I ("Revision in Don Quixote, Pt. I," in Hispanic Studies in Honour of Ignacio González Llubera, ed. Frank Pierce, Oxford: The Dolphin Book Co., 1959 , pp. 347-366, translated as "Cervantes revisa su novela (Don Quijote, I Parte)," Anales de la Universidad de Chile, CXXIV, no. 140 (Oct. - Dec., 1966), 5-33; see also his "Sobre el plan primitivo del Quijote," in Actas del $1^{\text {er }}$ congreso de hispanistas, Oxford: The Dolphin Book Co., 1964, pp. 463-471); and he admits the possibility that the episode of the batanes in Pt. II, ch. 29 was originally destined for Pt. I of the novel. Yet he fails to give due weight to this evidence in his approach to the composition of Pt. II. His arguments must be modified by the acceptance of the possibility that not all of these chapters were written during the period he proposes, and that some passages and incidents could have been written later (or, for that matter, some earlier).

58 Ed. cit., vol. 1, p. 206.

59 Obras Completas, ed. Valbuena Prat, 16th ed. (Madrid: Aguilar), 1970, p. 1042.

60 Ruth El Saffar, Novel to Romance, p. 50, n. 45 summarizes views on the date of the tale.

61 "Cervantes' Licenciado Vidriera: Its Form and Substance," West Virginia University Philological Papers, 8 (1951), 13-21, esp. p. 13. Cited by El Saffar, op. cit., p. 51, n. 46.

62 Ed. cit., vol. 2, p. 1019.

63 Obras Completas, ed. Valbuena Prat, p. 91.

64 Ed. cit., p. 182.

65 Ed. cit., p. 448.

66 Ed. cit., vol. 2, p. 982. 